\title{
ANALISIS PENGARUH ANTARA MUTU PRODUK, PELAYANAN PURNA JUAL DAN EKUITAS MEREK TERHADAP CITRA MEREK SMARTPHONE SAMSUNG
}

\author{
Arifin Sitio \\ Magister Manajemen \\ Universitas Mercu Buana \\ Email: arifin_sitio@yahoo.com \\ R. Rusnali \\ Magister Manajemen \\ Unirvesitas Dirgantara Marsekal Suryadarma
}

\begin{abstract}
Abstrak
Tujuan dari penelitian ini adalah untuk mengetahui: (1) Pengaruh antara mutu produk dengan citra merek,(2) Pengaruh antara pelayanan purnajual dengan citra merek, (3) Pengaruh antara ekuitas merek dengan citra merek. Hipotesis penelitian adalah sebagai berikut : (1) terdapat Pengaruh positif antara mutu produk dengan citra merek. (2) terdapat Pengaruh positif antara pelayanan purnajual dengan citra merek. (3) terdapat Pengaruh positif antara ekuitas merek dengan citra merek. Metode yang digunakan dalam penelitian ini adalah metode survey pada karyawan PT Mercedes-Benz Indonesia. Jumlah responden sebnya 123 orang yang dipilih dengan non probability sampling dengan metode convenience samling Dari 123 target responden, hanya 74 responden yang mengembalikan instrument penelitian. Data yang dikumpulkan berdasarkan instrumen penelitian berbentuk kuesionar yang telah dikalibrasi. Uji asumsi klasik dengan menggunakan: Uji Normalitas dan Uji Homogenitas. Penelitian Menyimpulkan bahwa: Pertama, ditemukan bahwa mutu produk $\left(\mathrm{X}_{1}\right)$ mempunyai Pengaruh positif dengan citra merek artinya makin tinggi mutu produk, maka citra merek akan semakin baik. Jika mutu produk lebih ditingkatkan dan diarahkan secara positif, maka citra merek juga akan leih meningkat atau lebih positif. Kedua, ditemukan bahwa pelayanan purnajual $\left(\mathrm{X}_{2}\right)$ mempunyai Pengaruh positif dengan citra merek artinya makin tinggi pelayanan purnajual, maka citra merek akan semakin baik. Jika pelayanan purnajual lebih ditingkatkan dan diarahkan secara positif, maka citra merek juga akan lebih meningkat atau lebih positif. Ketiga, ditemukan bahwa ekuitas merek $\left(\mathrm{X}_{3}\right)$ mempunyai Pengaruh positif dengan citra merek artinya makin tinggi ekuitas merek, maka citra merek akan semakin baik. Jika pelayanan purnajual lebih ditingkatkan dan diarahkan secara positif, maka citra merek juga akan lebih meningkat atau lebih positif.

Kata kunci:

Kualitas Produk, Pelayanan Purna Jual, Ekuitas Merek, Citra Merek
\end{abstract}




\begin{abstract}
The purpose of this study is to determine: (1) the impact of quality product to brand image, (2) the impact of post-sale service to brand image, (3) the impact of brand equity to brand image, Samsung Android smartphones. The research hypotheses are as follows: (1) there is a positive impact between the quality product to brand image. (2) there is a positive impactbetween post-sale service to brand image. (3) there is a positive impact between brand equity to brand image.. The method used in this research is survey method the employees of PT Mercedes-Benz Indonesia. 123 respondents are selected with non probability sampling with convinience sampling method. Only 74 questionnaire that returned. Classic assumption test that used: Normality test, test of homogeneity and multicoliniearity. Research Concludes that quality product $\left(\mathrm{X}_{1}\right)$ has a positive impact to brand image means that the higher the quality of the product, the brand image, the better. If the product quality further improved and redirected positively, then the brand image will also leih increased or more positive. Secondly, it was found that the post-sale service $\left(\mathrm{X}_{2}\right)$ has a positive impact to brand image means that the higher the sales service, the brand image, the better. If further enhanced after-sales service and redirected positively, then the brand image will also be increased or more positive. Thirdly, it was found that brand equity $\left(\mathrm{X}_{3}\right)$ has a positive impact to brand image means that the higher the brand equity, then the image of the brand, the better If further enhanced after-sales service and redirected positively, then the brand image will also be increased or more positive.
\end{abstract}

Keywords: Quality Product, Post-sale Service, Brand Equity, Brand Image 


\section{PENDAHULUAN}

\subsection{Latar Belakang}

Citra merek menjadi pertimbangan awal ketika sebagian orang hendak mengambil keputusan membeli suatu produk dan atau jasa. Salah satu contoh adalah keputusan pembelian produk berteknologi tinggi seperti smartphone. Saat ini berbagai tipe smartphone bersaing menguasai market share. Hasil penelitian Lomas (2014) menyebutkan bahwa pertumbuhan dan perkembangan pangsa pasar global android mendominasi pangsa pasar smartphone sebesar 79\%. Di Indonesia sendiri, salah satu dari tiga merek smartphone berbasis android yang menguasai pasar adalah merek Samsung (Indonesia Brand Champion Award, 2013).

Nama merek merupakan tanda pengenal di benak konsumen yang harus bersaing dengan merek lainnnya, hingga akhirnya menjadi merek pilihan konsumen.
Hal ini juga harus dilakukan oleh merek Samsung, khususnya jika ingin menguasai pasar Indonesia. Merek yang kuat akan membuat suatu produk lebih menonjol walaupun berada diantara produk-produk sejenis yang beredar di pasaran. Merek dapat dijadikan representasi perusahaan dan tidak dapat dipisahkan dari eksistensi produk. Persaingan yang ketat pada pasar smartphone berbasis android membuat perusahaan-perusahaan yang bergerak dalam teknologi ini berlomba-lomba untuk meningkatkan kualitas produknya dan menampilkan diferensiasi produknya. Faktor competitive advantage yang dimiliki smartphone berbasis Android seperti akses layanan email, ragam media sosial, fitur layanan virtual dan perangkat lunak yang bersifat open source merupakan ekuitas merek yang dimiliki oleh Android yang ikut memperkuat keunggulan citra merek pada smartphohe Android. Smartphone Samsung yang berbasis Android juga memiliki fitur- 
fitur tersebut dan membuat merek ini sangat digemari di pasar Indonesia. Ditambah lagi dengan desain yang stylish, membuat merek ini makin menjadi merek yang dicari oleh konsumen smartphone di Indonesia.

Dalam jangka panjang, keunggulan kompetitif yang berkesinambungan menjadikan kinerja merek bekerja di atas rata-rata. Hal ini akan berkaitan dengan peran nyata mutu produk dan pelayanan purna jual. Kesalahan dalam pengelolaan dua hal tersebut dapat berakibat pada penurunan citra merek di mata konsumen.

Setiap pelanggan produk, termasuk pelanggan smartphone Samsung berharap pelayanan yang mengesankan dan memuaskan pasca pembelian produk. Garansi produk menjadi suatu jaminan, kemudahan jangkauan serta jaringan service center, pelayanan yang ramah merupakan bahan pertimbangan konsumen untuk pembelian ulang di masa mendatang atau beralih kepada merek lain.
Dari kesemua hal di atas, penulis memutuskan untuk mengangkat suatu permasalahan Pengaruh mutu produk, pelayanan purna jual dan ekuitas merek terhadap citra merek patut untuk dijadikan topik bahasan penelitian terkait produk smartphone Android Samsung.

\subsection{Perumusan Masalah}

Berikut adalah rumusan masalah penelitian:

1. Apakah terdapat Pengaruh mutu produk terhadap citra merek smartphone Android Samsung?

2.Apakah terdapat Pengaruh pelayanan purna jual terhadap citra merek smartphone Android Samsung?

3.Apakah terdapat Pengaruh ekuitas merek terhadap citra merek smartphone Android Samsung? 


\section{KAJIAN TEORITIS DAN PENGAJUAN HIPOTESIS}

\subsection{Pengertian Citra Merek}

Citra

$$
\text { merek }
$$

menurut

Brandchannel.com diartikan sebagai potongan/bagian dari pilihan konsumen terhadap suatu merek. Bagi pengguna, ini berdasarkan pengalaman praktis terhadap produk atau jasa (kesan yang diketahui) dan sejauh mana harapan konsumen terpenuhi, sedangkan bagi yang bukan pengguna, citra merek hampir keseluruhan berdasarkan kesan yang tidak diketahui, sikap dan kepercayaan (Brandcareers-glossary,2014).

Pengertian citra merek tersebut menjadikan dua bagian penting yang bertolak belakang namun bergerak pada alur yang sama. Dari segi untuk pengguna/pelanggan (users), mereka mendasarkan perilakunya pada pengalaman sehingga timbul kesan yang sudah dikenali dan dirasakan ketika memakai suatu produk atau jasa sehingga bisa menilai sejauh mana kriteria itu memenuhi keinginan dan harapan mereka. Sedangkan untuk bukan pengguna/pelanggan (for non-users), mereka hanya mendapati citra merek dari hasil sikap dan kepercayaan yang ada terhadap suatu produk atau layanan.

Faktor-faktor yang membentuk citra merek dalam pandangan Keller antara lain; (1) Strength of brand association (kekuatan dari asosiasi merek); ini tergantung pada bagaimana informasi masuk ke dalam ingatan konsumen dan bagaimana informasi tersebut bertahan sebagai bagian dari brand image (citra merek). (2) Favourablitiy of brand association (kebaikan dari asosiasi merek); kesuksesan sebuah proses pemasaran sering tergantung pada proses terciptanya asosiasi merek yang menguntungkan, dimana konsumen dapat percaya pada atribut yang diberikan kepada mereka, dapat memuaskan kebutuhan dan keinginan konsumen. (3) Uniqueness of 
brand association (keunikan dari asosiasi merek); suatu merek haruslah memiliki keunggulan bersaing yang menjadi alasan bagi konsumen untuk memilih merek tertentu (Kevin L. Keller,1993:3). Keunikan asosiasi merek dapat dirasakan dari atribut produk, fungsi produk atau citra yang dinikmati konsumen. Intisarinya ialah faktorfaktor pembentuk citra merek itu memang bentuk tantangan yang memadai untuk pemasar bagaimana mengomunikasikan produk dan jasa yang mereka tawarkan agar mendapat tempat di hati dan pikiran konsumen.

Tingkatan citra merek adalah pengukuran bagaimana keberadaan suatu merek melewati berbagai macam parameter. Citra merek terdiri dari keunggulan, citra penggunaan, citra pengguna dan pengalaman. Citra merek harus mengukur pada keunggulan spesifiknya, bagaimana orang yang menggunakan merek tersebut, dan perbedaan penggunaannya pada beberapa jenis produk (M. G. Parameswaran , 2006:36).

Sementara pengertian Citra merek adalah gebyar dari seluruh asosiasi yang terkait pada suatu merek yang sudah ada di benak konsumen (Kartajaya, 2005:6). Pendapat ini memberi penekanan pada sifat asoasiasi yang sudah terbentuk. Ini menjelaskan penciptaan citra suatu merek diawali dari asosiasi yang panjang bahkan mungkin sebelum konsumen mencoba dan menggunakan suatu produk atau jasa. Pembentukan citra merek ini dipengaruhi oleh aspek pengalaman konsumen. Jadi, faktor yang paling dominan yang dijelaskan dalam definisi tersebut adalah asosiasi yang terbentuk dari pengalaman.

Dari definisi definisi citra merek yang telah diuraikan di atas, maka dapat disintesiskan citra merek adalah sekumpulan sikap yang diambil tentang gambaran yang tercermin dalam benak dan pikiran konsumen untuk menilai suatu merek yang 
dengan dimensi yakni; (1) pengenalan (recognition), (2) reputasi (reputation), (3) daya tarik atau simpati (affinity) dan (4) kesetiaan (loyalty).

\subsection{Pengertian Mutu Produk}

Oakland menguraikan perihal mutu secara sederhana diartikan sebagai kesesuaian dengan persyaratan yang dinginkan oleh konsumen (Oakland, 2003). Sementara itu, Crosby mendefinisikan kualitas sebagai ketepatan dalam persyaratan (Oakland , 2003). Dengan demikian, pada intinya kualitas sering dipakai untuk menandakan kesempurnaan suatu produk atau jasa.

Dewasa ini manajemen mutu mendapat perhatian besar dan ditandai dengan ragam teori dan aplikasi dari Total Quality Management (TQM). Beberapa penjelasan selanjutnya akan menyinggung definisi kontemporer dari Total Quality Management atau Manajemen Mutu Total antara lain; menurut Hansson dan Klefsjö, Total Quality Management (TQM) didefinisikan sebagai sebuah sistem manajemen yang terdiri dari tiga unit independen berupa core values (nilai-nilai inti), techniques (teknis) dan tools (Hansson,2003). Ide itu muncul dari konsep bahwa core values (nilai-nilai inti) haruslah didukung oleh hal-hal teknis (techniques) contohnya manajemen proses, studi perbandingan, perencanaan yang berfokus pada pelanggan, atau tim perbaikan (improvement team) dan didukung oleh peralatan (tools) seperti diagram kontrol, the quality house (bagan kualitas bermodelkan rumah), atau diagram Ishikawa untuk menjadi bagian dari budaya. Tujuan utama dari TQM menurut mereka berdua adalah untuk meningkatkan kepuasan pelanggan dengan mengurangi sejumlah sumber daya (Hansson,2003:73).

Beberapa prinsip dari manajemen mutu yang terkandung dalam ISO 9001 
diantaranya; (a) fokus pada pelanggan (customer focus), (b) kepemimpinan (leadership), (c) keterlibatan orang (involvement of people), (d) pendekatan proses (process approach), (e) pendekatan sistem untuk manajemen (system approach to management), (f) perbaikan terus-menerus (continuous improvement), (g) pendekatan faktual untuk pengambilan keputusan (factual approach to decision making) dan (h) Pengaruh pemasok yang bermanfaat untuk kedua belah pihak (mutually beneficial supplier relationships). Singkatnya, kedelapan hal itu memandu organisasi agar lebih teratur dan memberi perhatian penuh pada proses pelaksanaan manajemen dari perencanaan hingga evaluasi.

Schlickman, (2003) menandai tiga karakteristik pada definisi sistem manajemen mutu (Quality Manajemen System) berdasarkan ISO 9000:2000, yaitu; (1) pembuatan kebijakan dan tujuan yang harus dikelola oleh sebuah organisasi, (2) penugasan tanggung jawab dan kewenangan anggota dan (3) pengembangan struktur organisasi diantara para anggota (Schlickman, 2003). Kita melihat bahwa Schlickman berusaha lebih menekankan pada komponen inti organisasi sebagai pelaksana dan pengendali sistem manajemen mutu apalagi dalam menangani produkproduk. Dari beberapa definisi dapat disintesiskan mutu produk adalah manajemen yang terorganisir terkait kelayakan suatu produk atau jasa dari prapenjualan hingga pascapenjualan dengan dimensi meliputi; (1) tanggung jawab produk (product liability), (2) kualitas kinerja (performance quality) dan (3) kualitas ketepatan (conformance quality).

\subsection{Pengertian Pelayanan Purnajual}

Konsumen seakan terus merasa terhubung dengan produsen ketika ada jaminan dan pelayanan yang menyatakan produk yang mereka pakai adalah produk 
yang bermutu pantas dengan bukti keseriusan dukungan layanan purnajual dari produsen. Kotler memaknai layanan purnajual sebagai layanan yang diberikan perusahaan kepada konsumen setelah terjadinya transaksi penjualan yang dibagi menjadi departemen pelayanan pelanggan, jasa perbaikan dan pemeliharaan (Kotler, 2012). Di sini Kotler menekankan bahwa pelayanan purnajual tergabung dari tiga sisi yakni pelayanan pelanggan, jasa perbaikan dan pemeliharaan.

Pelayanan purnajual akan bermuara pada kepuasan pelanggan sehingga perlu adanya pengukuran kinerja dari mulai tingkat kepuasan pelanggan (customer satisfaction), retensi pelanggan (customer retention), akuisisi pelanggan (customer acquisition), pangsa pasar (market share) hingga keuntungan pelanggan (customer profitability) (Kotler, 2002). Dari banyak pengertian di atas, satu hal yang mirip adalah mereka semua ialah kegiatan yang menggerakkan dan menumbuhkan pelayanan purnajual dengan tujuan intinya adalah untuk kepuasan konsumen.

Sintesis teori pelayanan purnajual pelanggan didefinisikan sebagai suatu kegiatan pascatransaksi setelah penyerahan produk atau jasa dari produsen kepada konsumen yang merupakan bentuk layanan yang berlaku selama ikatan layanan atau Pengaruh dalam kegiatan pemasaran dengan dimensi yakni; (1) garansi (warranty), (2) penyediaan aksesoris (accessories), (3) pelayanan perbaikan (reparation) dan (4) fasilitas (facilities).

\subsection{Pengertian Ekuitas Merek}

Yoo dan Donthu (2001) meninjau sederetan definisi dan bentuk dari ekuitas merek yang mencakup hal-hal berupa watak dan sikap (attitudinal dispositions), nilai tambah (added value), kesadaran pada suatu merek (brand awareness), aset suatu merek (brand assets). Dari rangkaian tersebut, kita 
memperolah refleksi pengertian yang tersirat dari pemahaman terhadap suatu merek yang berarti cara pandang konsumen dan cara pandang perusahaan dimana keduanya mengakibatkan perbedaan pengukuran nilai dari brand equity (ekuitas merek).

Sementara Aaker dalam Tjiptono (2005), menjelaskan ekuitas merek sebagai serangkaian aset dan kewajiban merek yang terkait dengan sebuah merek, nama merek, dan simbolnya, yang menambah atau mengurangi nilai yang diberikan sebuah produk atau jasa kepada perusahaan dan atau pelanggan perusahaan tersebut. Jadi, definisi ini mengandung unsur emosional dan praktis yang mempengaruhi ukuran suatu ekuitas merek.

Kotler (2002) membagi tingkatan nilai suatu merek dalam empat tingkat dari yang terendah hingga tertinggi meliputi; (1) kesadaran merek (brand awareness), (2) penerimaan merek (brand acceptability), (3) preferensi merek (brand preference) dan (4) kesetiaan merek (brand loyalty). Dari empat tingkatan yang dikelompokkan di atas, kita melihat adanya faktor pengenalan (recognition) suatu merek yang harus ada untuk memunculkan tingkatan kesadaran akan suatu merek. Tingkatan loyal ialah tahap di saat pelanggan tidak lagi berpikir tentang suatu merek dan berpindah merek, mereka menganggap merek sebagai teman akrab yang tidak bisa ditinggalkan begitu saja. Tentu saja, taraf kesetiaan merek semestinya dibangun dalam kerangka strategi pemasaran yang terus-menerus baik agar kekecewaan pelanggan tidak harus muncul.

Ekuitas merek yang tinggi memiliki keuntungan kompetitif antara lain; (a) perusahaan akan menikmati biaya pemasaran yang lebih kecil karena kesadaran dan kesetiaan merek konsumen yang tinggi, (b) perusahaan akan mempunyai posisi yang lebih kuat dalam negosiasi dengan distributor dan pengecer karena pelanggan 
mengharapkan mereka untuk menjual merek tersebut, (c) perusahaan dapat mengenakan harga yang lebih tinggi daripada pesaingnya karena merek tersebut memiliki mutu yang diyakini lebih tinggi, (d) perusahaan lebih mudah untuk meluncurkan perluasan merek karena merek tersebut memiliki kredibilitas tinggi, (e) merek itu melindungi perusahaan dari persaingan harga yang ganas (Kotler (2002). Tentu saja hal-hal tersebut berpengaruh pada setinggi apa ekuitas merek bisa mempengaruhi rasa percaya diri konsumen dalam mengambil keputusan membeli sehingga perlu upaya untuk terus mempertahankan dan meningkatkan ekuitas merek agar tidak menyusut.

Menurut Kapferer (2008) ketika suatu merek ingin mendapatkan tempat yang baik dan bisa memimpin dalam pangsa pasar maka merek harus; (1) mampu menelurkan ide besar dan atraktif, (2) dirasakan oleh orang melalui kontak langsung, (3) diaktifkan oleh perilaku, (4) dikomunikasikan dan (5) terdistribusi83. Keunikan kelima aspek tersebut di antara produsen dengan konsumen harus berdampingan harmonis dimana produsen menciptakan dan mengidentifikasi setiap kebutuhan konsumen serta di saat yang sama konsumen merespon dengan kontak langsung yang menguntungkan. Konsep tentang bagaimana menelurkan ide besar yang sekaligus atraktif, dipicu perilaku, dikomunikasikan, didistribusikan pada nilainilai yang terkandung dan melekat, kemudian membutuhkan keselarasan yang harmonis menuju kesetiaan pelanggan yang senantiasa diarahkan untuk kepentingan jangka panjang.

Dalam riset yang dilakukan oleh Krishnan dan Hartline terkait ekuitas merek, mereka menyajikan beberapa teori contohya teori dari Aaker yang mengidentifikasi empat basis besar yang berkaitan dengan konsumen pada suatu ekuitas merek adalah (a) brand loyalty (loyalitas merek), (b) name 
awareness (kesadaran nama), (c) perceived quality (kualitas persepsi), (d) other brand associations (Krishnan dan Hartline, 2001).

Sintesis teori dari banyak definisi sebelumnya terkait ekuitas merek terangkum dalam pengertian ekuitas merek yang bermakna nilai yang terkandung dalam nama, simbol maupun kombinasi merek lainnya pada produk dan jasa suatu perusahaan yang bisa menambah atau mengurangi nilai kepercayaan dan kesetiaan pelanggan, dengan dimensi: (1) nilai yang melekat (attached value), (2) penghormatan pada merek (respect) dan (3) penilaian (judgement).

\subsection{Hipotesis Penelitian}

Berikut hipotesis-hipotesis pada penelitian ini:

Hipotesis 1: terdapat Pengaruh positif mutu produk terhadap citra merek.

Hipotesis 2: terdapat Pengaruh positif pelayanan purna jual terhadap citra merek.
Hipotesis 3: terdapat Pengaruh positif ekuitas merek terhadap citra merek.

\section{METODE PENELITIAN}

\subsection{Tujuan Penelitian}

Secara umum penelitian untuk mendeskripsikan data penelitian mengenai citra merek (Y), mutu produk $\left(\mathrm{X}_{1}\right)$, pelayanan purnajual $\left(\mathrm{X}_{2}\right)$, ekuitas merek $\left(\mathrm{X}_{3}\right)$. Berdasarkan perumusan masalah yang telah diuraikan pada bab I, maka secara khusus penelitian ini bertujuan untuk: (1). Untuk mengetahui bentuk Pengaruh antara mutu produk dengan citra merek. (2) untuk mengetahui bentuk Pengaruh antara pelayanan purnajual dengan citra merek. (3) untuk mengetahui Pengaruh antara ekuitas merek dengan citra merek.

Penelitian ini adalah penelitian survey dengan teknik penarikan sampel yang digunakan adalah non probability sampling dengan metode convenience sampling. 
jumlah sampel adalah 74 orang pengguna smart phone Samsung oleh karyawan PT. Mercedez Benz.

\subsection{Definisi Operasional Variabel Citra Merek (Y)}

Definisi operasional citra merek adalah skor total tanggapan responden mengenai sekumpulan sikap yang diambil tentang gambaran yang tercermin dalam benak dan pikiran konsumen untuk menilai suatu merek yang meliputi empat dimensi yakni; (1) pengenalan (recognition), (2) reputasi (reputation), (3) daya tarik atau simpati (affinity) dan (4) kesetiaan (loyalty), menggunakan skala Likert dengan tingkatan (1) Sangat Tidak Baik, (2) Tidak Baik, (3) Cukup Baik, (4) Baik dan (5) Sangat Baik. Definisi operasional mutu $\left(\mathrm{X}_{1}\right)$ produk adalah skor tanggapan responden mengenai manajemen yang terorganisir terkait kelayakan suatu produk atau jasa dari prapenjualan hingga pascapenjualan dengan lingkup dimensi meliputi; (1) tanggung jawab produk (product liability), (2) kualitas kinerja (performance quality) dan (3) kualitas ketepatan (conformance quality), menggunakan skala Likert dengan tingkatan (1) Sangat Tidak Baik, (2) Tidak Baik, (3) Cukup Baik, (4) Baik dan (5) Sangat Baik. Definisi operasional pelayanan purnajual $\left(\mathrm{X}_{2}\right)$ adalah skor tanggapan responden mengenai suatu kegiatan pascatransaksi setelah penyerahan produk atau jasa dari produsen kepada konsumen yang merupakan bentuk layanan yang berlaku selama ikatan layanan dalam kegiatan pemasaran dengan dimensi antara lain; (1) garansi (warranty), (2) penyediaan aksesoris (accessories), (3) pelayanan perbaikan (reparation) dan (4) fasilitas (facilities), menggunakan skala Likert dengan tingkatan (1) Sangat Tidak Puas, (2) Tidak Puas, (3) Cukup Puas, (4) Puas dan (5) Sangat Puas. Berikut tabel 3 untuk variabel $\mathrm{X} 2$. 
Definisi operasional ekuitas merek

$\left(\mathrm{X}_{3}\right)$ adalah skor tanggapan responden mengenai nilai yang terkandung dalam nama, simbol maupun kombinasi merek lainnya pada produk dan jasa suatu perusahaan yang bisa menambah atau mengurangi nilai kepercayaan dan kesetiaan pelanggan, dimensinya antara lain; (1) nilai yang melekat (attached value), (2) penghormatan pada merek (respect) dan (3) penilaian (judgement), menggunakan skala Likert dengan tingkatan (1) Sangat Tidak Baik, (2) Tidak Baik, (3) Cukup Baik, (4)

\subsection{Teknik Analisis}

Analisis data penelitian dilakukan dengan langkah-langkah sebagai berikut:

1.Analisis deskriptif yang digunakan adalah tabel frekuensi tabulasi penilaian menggunakan jarak yang dapat dihitung melalui nilai tertinggi dan terendah dengan rumus sebagai berikut:

Bobot $\mathrm{x}$ Penilaian $=$ Total Kumulatif Akhir Rumus ini dikombinasikan dengan rumus mencari banyak kelas yang dibutuhkan yaitu sebagai berikut (Tabel 1. Tabel 2 . Tabel 3. dan Tabel 4.):

Baik dan (5) Sangat Baik.

Tabel 1.

Interval penilaian Variabel Citra Merek (Y)

\begin{tabular}{|l|l|l||}
\hline Level & Kategori Penilaian & Rentang Nilai \\
\hline \hline I & $\begin{array}{l}\text { Citra Pengalaman (Experience } \\
\text { Image) }\end{array}$ & $451-615$ \\
\hline \hline II & Citra Pengguna (User Image) & $287-450.99$ \\
\hline \hline III & $\begin{array}{l}\text { Citra Penggunaan (Usage } \\
\text { Image) }\end{array}$ & $123-286.99$ \\
\hline
\end{tabular}


Tabel 2.

Interval Penilaian untuk Variabel Mutu Produk (X1)

\begin{tabular}{|l|l||l||}
\hline Level & Kategori Penilaian & Rentang Nilai \\
\hline \hline I & $\begin{array}{l}\text { Jaminan Mutu (Quality } \\
\text { Assurance) }\end{array}$ & $492-615$ \\
\hline II & $\begin{array}{l}\text { Peningkatan Mutu (Quality } \\
\text { Improvement) }\end{array}$ & $369-491.99$ \\
\hline \hline III & $\begin{array}{l}\text { Pengawasan Mutu (Quality } \\
\text { Control) }\end{array}$ & 246-168.99 \\
\hline \hline IV & $\begin{array}{l}\text { Perencanaan Mutu (Quality } \\
\text { Planning) }\end{array}$ & $123-245.99$ \\
\hline
\end{tabular}

Tabel 3.

Interval Penilaian untuk Pelayanan Purna Jual (X2)

\begin{tabular}{|l||l||l||}
\hline Level & Kategori Penilaian & Rentang Nilai \\
\hline \hline I & $\begin{array}{l}\text { Profitabilitas Pelanggan } \\
\text { (Costumer Profitability) }\end{array}$ & 516.60-615 \\
\hline \hline II & Pangsa Pasar (market share) & $418.20-516.59$ \\
\hline \hline III & $\begin{array}{l}\text { Akuisisi Pelanggan (customer } \\
\text { acquisition) }\end{array}$ & $319.80-418.19$ \\
\hline \hline IV & $\begin{array}{l}\text { Retensi Pelanggan (Customer } \\
\text { Retention) }\end{array}$ & 221.40-319.79 \\
\hline \hline V & $\begin{array}{l}\text { Kepuasan Pelanggan } \\
\text { (Customer Satisfaction) }\end{array}$ & $123-221.39$ \\
\hline
\end{tabular}

Tabel 4.

Interval Penilaian untuk Ekuitas Merek(X3)

\begin{tabular}{|l|l||l||}
\hline \hline Level & Kategori Penilaian & Rentang Nilai \\
\hline \hline I & $\begin{array}{l}\text { Kesetiaan Merek (Brand } \\
\text { Loyalty) }\end{array}$ & $492-615$ \\
\hline \hline II & $\begin{array}{l}\text { Preferensi Merek (Brand } \\
\text { Preference) }\end{array}$ & $369-491.99$ \\
\hline \hline III & $\begin{array}{l}\text { Akseptabilitas Merek (Brand } \\
\text { Acceptability) }\end{array}$ & 246-368.99 \\
\hline \hline IV & $\begin{array}{l}\text { Kesadaran Merek (Brand } \\
\text { Awareness) }\end{array}$ & $123-245.99$ \\
\hline
\end{tabular}

Data penelitian dianalisis secara deskriptif untuk menjelaskan deskripsi data penelitian.

2.Uji asumsi klasik yang dilakukan terdiri a. Uji normalitas

Dengan menggunakan rumus Liliefors. Uji liliefors dilakukan untuk mengetahui apakah data berdistribusi normal, jika dari: 
$\mathrm{L}_{\text {hitung }}<\mathrm{L}_{\text {tabel }}$ maka regresi $\mathrm{Y}$ atas $\mathrm{X}_{1}, \mathrm{X}_{2}$, dan $\mathrm{X}_{3}$ dinyatakan berdistribusi normal.

b.Uji Homogenitas

Uji homogenitas dengan menggunakan Metode Glejser dengan meregresikan nilai absolud residual yang diperoleh. Dimana jika nilai sig $>0,05$ maka tidak terjadi heterokedastisitas dan jika nilai sig $<0,05$ maka terjadi heterokedastisitas.

\section{c. Uji Multikolinearitas}

Uji Multikolinearitas bertujuan untuk mengetahui apakah terdapat hubungan kolinier antar variabel independen. Pengujian dilakukan dengan menggunakan Metode Varian Inflation Factor (VIF) dan nilai tolerance. Variabel dikatakan memiliki masalah multikolinearitas jika nilai tolerance < 0.1 dan nilai VIF > 10 (Hair et al, 1995).

3.Uji regresi berganda dilakukan dengan menggunakan statistik inferensial yaitu regresi berganda menggunakan Program SPSS 20.

\section{HASIL PENELITIAN DAN PEMBAHASAN}

\subsection{Deskripsi Data}

Data hasil penelitian ditabulasi ke dalam tabel distribusi frekuensi statistik deskriptif yang akan menggambarkan central tendency; mean, median dan modus. Hal-hal tersebut akan banyak membantu baik dalam tahapan pengujian persyaratan analisis ataupun pengujian hipotesis dari statistik deskriptif dan inferensial (induktif) yang selanjutnya digunakan sebagai dasar pertimbangan pengambilan kesimpulan akhir dari studi yang dilakukan sesuai tujuan penelitian yang hendak dicapai.

Deskripsi variabel yang ditunjukkan dalam Tabel 5. adalah rangkuman dan penilaian responden terhadap instrumen penelitian. Dari hasil penelitian lapangan 
yang telah dilaksanakan menggambarkan tanggapan responden pengguna telepon genggam merk Samsung terhadap masingmasing instrumen variabel adalah sebagai berikut:

1. Citra Merk (Y), dari hasil tanggapan responden nilai Mean dari skort total citra merek sebesar 91,91 artinya responden menilai citra merek produk smartphone Android Samsung masih berada pada level citra penggunaan (usage image). Artinya Konsumen cenderung menilai baik karena kepuasan dan pencapaian merek dari sisi keunggulan penggunaannya, mobilitas seperti aspek fitur, nama yang mudah diucap atau dikenal dan jaringan merek, namun tidak banyak mendorong konsumen untuk menjadi fanatik terhadap merek ini. Pada level ini konsumen menjadi lebih mudah tergoda untuk beralih pada tawaran merek lain yang dirasa lebih punya sisi mengesankan dan menjanjikan.
2.Dari hasil tanggapan responden mengenai mutu produk $\left(\mathrm{X}_{1}\right)$ dengan nilai rata-rata (mean) sebesar 98,74 menggambarkan Kesadaran Merek (Brand Awareness). Responden menilai mutu produk smartphone ini ada pada level perencanaan mutu (quality planning) dimana konsumen hanya mempercayai mutu produk berdasarkan mutu dasar pada tiap produk yang terdistribusi sebagai produk yang biasa untuk penggunaan biasa sehingga pada tingkatan ini konsumen belum cukup percaya pada jaminan perhatian serius produk.

3.Tanggapan responden mengenai Pelayanan purnajual $\left(\mathrm{X}_{2}\right)$ dengan niali rata (mean) sebesar 85,84 menggambar kepuasan pelanggan (Customer Satisfaction). Konsumen memandang pelayanan purna jual yang diselenggarakan oleh Samsung berorientasi pada tingkat kepuasan pelanggan (customer satisfaction) yakni pelayanan yang hanya berkisar soal 
bagaimana kepuasan konsumen terpenuhi pada layanan tahap dini dan reaktif.

4.Nilai rata-rata (mean) Ekuitas Merk $\left(\mathrm{X}_{3}\right)$ sebesar 97,38 menggambarkan kesadaran akan merk (brand awareness). Dalam arti suatu tahapan pengenalan produk dan tidak membuat efek yang menggiurkan untuk melakukan pembelian berulang, konsumen akan mudah beralih pada produk lain dan memilih produk yang punya nilai lebih tinggi dan kesan yang lebih kuat.

Tabel 5.

Tanggapan Responden Atas Varibel Mutu Produk, Pelayanan Purna Jual, Ekuitas Merk dan Citra Merk

\begin{tabular}{|l||l|l|l||l|l||}
\hline \multicolumn{5}{|c||}{ Tanggapan Responden atas Variabel } \\
\hline \hline Variabel & Median & Modus & Std Deviasi & \multicolumn{1}{|c||}{ Mean } \\
\hline $\begin{array}{l}\text { Mutu } \\
\text { Produk (X1) }\end{array}$ & 99,50 & 97 & 13,40 & 98,74 & $\begin{array}{l}\text { Kesadaran Merek } \\
\text { (Brand Awareness) }\end{array}$ \\
\hline \hline $\begin{array}{l}\text { Pelayanan } \\
\text { Purnajual (X2) }\end{array}$ & 84 & 90 & 13,04 & 85,84 & $\begin{array}{l}\text { kepuasan pelanggan } \\
\text { (Customer Satisfaction) }\end{array}$ \\
\hline $\begin{array}{l}\text { Ekuitas Merek } \\
\text { (X3) }\end{array}$ & 96,50 & 87 & 12,04 & 97,38 & $\begin{array}{l}\text { Kesadaran Merek (Brand } \\
\text { Awareness) }\end{array}$ \\
\hline \hline Citra Merek (Y) & 92 & 82 & 13,52 & 91,91 & $\begin{array}{l}\text { Citra Penggunaan } \\
\text { (Usage Image) }\end{array}$ \\
\hline
\end{tabular}

\subsection{Uji Asumsi Klasik}

Uji persyaratan analisis bertujuan untuk menganalisis data dari variabel Citra Merek (Y), Mutu Produk $\left(\mathrm{X}_{1}\right)$, Pelayanan Purnal Jual $\left(\mathrm{X}_{2}\right)$, dan Ekuitas Merek $\left(\mathrm{X}_{3}\right)$ melalui statistik inferensial yakni analisis regresi sehingga akan bisa diketahui apakah variabel-variabel tersebut sudah memenuhi syarat uji persyaratan analisis. Uji Asumsi Klasik meliputi:

\section{Uji Normalitas}

Hasil uji normalitas dengan uji Liliefors menunjukkan bahwa nilai Asymp.sig sebesar 0,067 >0,05 yang menunjukkan residual berdistribusi normal, maka model regresi telah memenuhi asumsi klasik normalitas.

\section{Uji Homogenitas}

Dari hasil Uji Glejser, didapatkan bahwa nilai signifikansi Mutu Produk (X1) 
sebesar $0,984>0,05$ maka tidak ada indikasi heterokedastisitas. Nilai signifikansi pelayanan purnajual sebesar $0,876>0,05$ mengindikasikan tidak terjadi heterokedastisitas, demikian juga dengan nilai signifikansi Ekuitas merek sebesar
$0,399>0,05$ mengindikasikan tidak terjadi heterokedastisitas.

\section{Uji Multikolinearitas}

Berikut pada Tabel 6. disajikan hasil uji multikolinearitas.

Tabel 6.

Hasil Uji Multikolinearitas

\begin{tabular}{||l||l||l||c||}
\hline Variabel X & VIF & Tolerance & Kesimpulan \\
\hline \hline X1 & 1,088 & 0,919 & Tidak ada multikolinearitas \\
\hline \hline X2 & 1,376 & 0,727 & Tidak ada multikolinearitas \\
\hline \hline X3 & 1,365 & 0,733 & Tidak ada multikolinearitas \\
\hline \multicolumn{2}{|c|}{ Variabel Y : Citra merek } \\
\hline
\end{tabular}

\subsection{Analisis Regresi Linier Berganda}

Analisis regresi linier berganda terbagi ke dalam tiga kelompok dimana masing-masing akan memberikan gambaran yang saling melengkapi satu sama lain dalam menggambarkan, menghubungkan, menilai, membaca, memahami, hingga memutuskan tentang sejauh mana pengaruh yang terbentuk secara parsial antar tiap variabel bebas (independen) dengan variabel terikat (dependen).
Kriteria penilaian yang dipakai dalam penelitian ini antara lain;

1. Uji koefisien determinasi untuk melihat persentase varian variabel independen menjelaskan varian variabel dependen.

Dari hasil uji regresi, diperoleh koefisien determinasi sebesar 0,518. Artinya 51,8\% varian variabel independen, yaitu mutu produk, pelayanan purnajual dan ekuitas merek dapat menjelaskan varian variabel citra merek. Sedangkan sisanya sebanyak 
$48,2 \%$ varian dijelaskan oleh variabel lain

di luar penelitian ini.

\section{Uji Kelayakan Model}

Uji F dilakukan untuk menguji kesesuaian model regresi linier berganda. Kriteria pengujian dilakukan dengan membandingkan perbandingan nilai $\mathrm{P}$ value (sig.) dengan nilai $\alpha$ yang ditetapkan sebesar 0,05 ketika nilai signifikansi > 0,05 maka menunjukkan bahwa model regresi tidak layak untuk digunakan untuk analisis selanjutnya. Namun, jika dan nilai signifikansi $\leq 0,05$ maka model regresi layak digunakan.

Tabel 7.

Hasil Uji ANOVA

ANOVA $^{\mathrm{a}}$

\begin{tabular}{|ll|r|r|r|r|l|}
\hline \multicolumn{2}{|c|}{} & \multicolumn{1}{c|}{$\begin{array}{c}\text { Sum of } \\
\text { Squares }\end{array}$} & \multicolumn{1}{c|}{ df } & Mean Square & \multicolumn{1}{c|}{$\mathrm{F}$} & \multicolumn{1}{l|}{ Sig. } \\
\hline 1 & Regression & 9.470 & 3 & 3.157 & 25.028 & $.000^{\mathrm{b}}$ \\
& Residual & 8.829 & 70 & .126 & & \\
& Total & 18.300 & 73 & & & \\
\hline
\end{tabular}

a. Dependent Variable: Citra_Merek

b. Predictors: (Constant), Ekuitas_merek, Mutu_Produk, Pelayanan_Purna_Jual

Berdasarkan Tabel 7. di atas, dapat dilihat bahwa nilai signifikansi $0,00<0,05$ sehingga dapat diambil kesimpulan bahwa model regresi layak digunakan untuk dapat dianalisis lebih lanjut.

\section{Uji Hipotesis}

Uji t untuk mengetahui pengaruh parsial masing-masing variabel independen terhadap variabel dependent, yang artinya menguji signifikansi pengaruh antara mutu produk, pelayanan purna jual dan ekuitas merek terhadap citra merek.

Kriteria pengujian dengan uji $t$ dengan membandingkan tingkat signifikansi dari nilai t $(\alpha=0,05)$ dengan ketentuan:

a. Jika tingkat signifikansi ujit $\leq 0,05$, hal ini menunjukkan bahwa terdapat pengaruh positif mutu produk, pelayanan purna jual dan ekuitas merek terhadap citra merek atau terima Hipotesis alternatif. 
b.Jika tingkat signifikansi ujit $>0,05$, hal ini menunjukkan bahwa tidak terdapat pengaruh mutu produk, pelayanan purna jual dan ekuitas merek terhadap citra merek (terima Ho).
Atau terdapat pengaruh negatif mutu produk, pelayanan purna jual dan ekuitas merek terhadap citra merek (terima Ho). Hasil pengujian parsial adalah sebagai berikut (Tabel 8.):

Tabel 8.

Hasil Uji Parsial

coefficients $^{\mathrm{a}}$

\begin{tabular}{|c|c|c|c|c|c|c|}
\hline \multirow[b]{2}{*}{ Mode } & & \multicolumn{2}{|c|}{ Unstandardzed Coefficients } & \multirow{2}{*}{$\begin{array}{c}\text { Standardized } \\
\text { Coefficients } \\
\text { Beta }\end{array}$} & \multirow[b]{2}{*}{1} & \multirow[b]{2}{*}{ Sig } \\
\hline & & B & Std. Error & & & \\
\hline \multirow[t]{4}{*}{1} & (Constanit) & -020 & 420 & & -047 & 962 \\
\hline & Musu_Produk & 182 & .091 & 173 & 1.997 & 050 \\
\hline & Pelayanan_Puma_Jual & 335 & .107 & .305 & 3.137 & .003 \\
\hline & Ehutas_merek & 514 & 113 & .442 & 4.553 & 000 \\
\hline
\end{tabular}

a. Dependent Variable: Citra_Merek

planning) yaitu kondisi dimana konsumen

\subsection{Pengaruh Mutu Produk terhadap}

\section{Citra Merek}

Dari tabel di atas diperoleh nilai signifikansi mutu produk sebesar 0,050, dimana nilai ini $=$ nilai $\alpha$ yang ditetapkan Dari hasil tersebut dapat disimpulkan terima H1 yang artinya terdapat pengaruf positif mutu produk terhadap citra merek.

Berdasarkan tanggapan responden mengenai mutu produk ini secara rata-rata berada pada level perencanaan mutu (quality hanya mempercayai mutu produk berdasarkan mutu dasar produk yang biasa untuk penggunaan biasa.

Sedangkan citra merek produk smartphone Android Samsung secara ratarata menempati level citra pengunaan (usage image) dimana konsumen cenderung menilai baik sebatas karena kepuasan dan pencapaian merek dari sisi keunggulan mobilitas penggunaan seperti fitur standar, nama yang 
mudah diucap dan dikenal, maupun jaringan merek yang ada.

\subsection{Pengaruh Pelayanan Purna Jual terhadap Citra Merek}

Nilai signifikansi dari pelayanan purna jual sebesar $0,03<0,05$, yang artinya terima H2. Dari hasil tersebut dapat disimpulkan bahwa terdapat pengaruh positif pelayanan purna jual terhadap citra merek.

Berdasarkan tanggapan responden mengenai pelayanan purnajual produk smartphone Android Samsung secara ratarata menempati level/tahap kepuasan pelanggan (customer satisfaction) yang hanya berkisar soal bagaimana kepuasan konsumen terpenuhi pada tahap dini dan reaktif. Bentuk Pengaruh positif menggambarkan apabila pelayanan purnajual ditingkatkan, maka citra merek akan meningkat.

\subsection{Pengaruh Ekuitas Merek terhadap Citra Merek}

Dari tabel di atas dapat dilihat bahwa nilai signifikansi ekuitas merek sebesar $0,000<0,05$, maka terima H3. Artinya terdapat pengaruh positif ekuitas merek terhadap citra merek.

Berdasarkan tanggapan responden mengenai ekuitas merek produk smartphone Android Samsung secara rata-rata menempati level kesadaran merek (brand awareness) yakni suatu tahapan pengenalan produk yang tidak membuat efek yang menggiurkan bagi konsumen sehingga beresiko terhadap kesetiaan pelanggan dimana citra merek ada pada citra penggunaan (usage image). Untuk meningkatkan citra merek, peningkatkatan pelayanan purnajual perlu ditingkatkan.

\subsection{Keterbatasan Penelitian}

Berikut beberapa keterbatasan dalam penelitian ini: 
1.Secara konseptual riset mengenai citra merek produk smartphone android Samsung ini hanya dibatasi oleh tiga variabel bebas yaitu; Mutu Produk $\left(\mathrm{X}_{1}\right)$, pelayanan purna jual $\left(\mathrm{X}_{2}\right)$ dan Ekuitas Merek $\left(\mathrm{X}_{3}\right)$ saja dimana mungkin ada variabel-variabel lain yang perlu untuk diuji dan diikutsertakan.

2.Penelitian menggunakan metode kuantitatif dengan metode convenience yang hanya ditujukan untuk para pengguna smartphone Android Samsung di PT. Mercedes Benz dengan batasan dan kategori yang telah ditetapkan sebagaimana telah diuraikan dalam metodologi penelitian, ini bisa menjadi kelemahan dalam hasil pengambilan kesimpulan dan akurasi pengambilan keputusan.

3.Perhitungan-perhitungan statistik dalam penelitian ini masih menggunakan pembulatan angka dengan tujuan untuk penyederhanaan dan pemudahan perhitungan yang hal-hal ini mungkin bisa mengurangi ketelitian dalam perumusan hingga penarikan kesimpulan.

4.Alokasi waktu dan biaya yang terbatas memaksa penelitian harus dibatasi pada variabel-variabel tertentu dengan kerangka waktu yang layak dan rasional untuk dilakukan dalam tenggat yang ada.

\subsection{Implikasi Penelitian}

Berikut adalah implikasi-implikasi dari penelitian ini :

\subsubsection{Pengendalian yang Serius dalam} Mutu Produk Smartphone Android Samsung Akan Berdampak pada Pembentukan Citra Merek yang Positif di Mata Konsumen.

Mutu produk memiliki rantai panjang mulai dari prapenjualan sampai dengan pascapenjualan. Rantai proses inilah yang membentuk simpul-simpul kekuatan 
citra merek dari suatu produk. Pengendalian yang ketat dalam tiap detail produk yang dijual kepada konsumen menjadi bentuk nyata implementasi mutu produk. Di saat yang bersamaan, konsumen sendiri melihat citra merek dari kinerja produk yang bisa memuaskan harapan mereka. Pada kondisi demikian, kualitas menjadi hal yang tidak mudah untuk ditawar karena konsumen mempunyai lebih banyak waktu dalam mencari kekurangan/kelemahan produk yang mereka pakai atau gunakan. Hal ini merupakan bagian dari bentuk kecintaan konsumen pada produk Samsung dengan berbagai smartphone Android yang telah dan sedang dipasarkan, memiliki standar dan batasan mutu produknya sendiri. Upayaupaya nyata yang berfokus pada mutu produk terlihat dari hal-hal diantaranya;

1.Tanggung jawab penuh terhadap produk (product liability) sebagai bentuk penjagaan kepercayaan konsumen terhadap produk yang mereka beli.
2.Menjaga konsistensi mutu dalam ketelitian dan ketepatan produk yang ditawarkan (conformance quality).

3. Menjamin ketangguhan kinerja produk (performance quality) ketika harus digunakan dalam kesempatan yang ekstrem sekalipun seperti goncangan, benturan, tekanan, pembebanan kerja perangkat, kompatibilitas perangkat lunak, jangkauan aplikasi dan sebagainya.

\subsubsection{Prioritas Pelayanan Purnajual} yang Sempurna Akan Menjadikan Smartphone Android Samsung Sebagai Merek dengan Citra yang Kokoh dan Dikenal Pasar

Pelayanan purnajual adalah bentuk ikatan hati penjual kepada konsumennya ke dalam bentuk yang lebih terbuka. Kegiatan pascatransaksi yang menghubungkan nilai kepercayaan konsumen terhadap kerja produk yang mereka gunakan. Smartphone Android Samsung ada dengan dukungan 
pelayanan purnajual yang tersebar di daerahdaerah. Ini menjadi bagian bukti keseriusan dalam hal satu ini. Dengan demikian usahausaha nyata terkait layanan yang begitu diharapkan oleh konsumen setidaknya bersumber pada 4 hal diantaranya;

1.Penegasan jaminan (warranty) dari produk yang telah dibeli, sejauh mana akan melindungi hak-hak konsumen dalam jangka waktu tertentu atau sebaliknya layanan akan terputus begitu saja dan memaksa konsumen menelan kekecewaan akibat pelayanan yang buruk.

2.Penyediaan beragam aksesoris (accessories) sebagai fitur spesial yang ditawarkan kepada konsumen dalam rangka pelayanan jangka panjang.

3.Layanan jasa perbaikan (reparation) yang memberikan solusi untuk keluhan terkait mutu kinerja produk dan spesifikasi produk

4.Pemenuhan pusat-pusat fasilitas yang tersedia (facilities) dalam layanan yang luas serta jangkauan yang tidak dibatasi area dan waktu. Pelayanan yang baik dan sempurna (excellence services) yang dirasakan konsumen akan semakin menumbuhkan kepercayaan yang tinggi pada produk tersebut sehingga citra merek semakin baik, dalam hal ini adalah citra merek smartphone Android Samsung.

\subsubsection{Ekuitas Positif Merek yang} Melekat pada Smartphone Android Samsung Akan Menimbulkan Kepercayaan Pasar yang Tinggi pada Citra Merek

\section{Produk Ini}

Nilai merek yang merupakan bentuk respon kepercayaan (trust) dan kesetiaan (loyalty) konsumen terhadap citra merek produk. Dalam hal ini, konsumen memilih untuk membeli smartphone Android Samsung atas rasa percaya diri yang terbentuk dari ekuitas merek yang terkandung didalamnya. Oleh karena itu, 
upaya-upaya untuk menjaga ekuitas merek smartphone Android Samsung setidaknya berpijak pada hal-hal inti antara lain; (a) membenahi nilai yang menyertai/melekat (attached value) pada merek unik yang satu ini, (b) merangsang antusiasme konsumen untuk lebih menghormati merek (respect) Samsung (c) perbaikan penilaian (judgement) dalam hal bagaimana mutu merek ini mampu memenuhi keinginan dan kebutuhan inti para pengguna smartphone pada umumnya. Implikasi nyata yang terbentuk adalah kepercayaan tinggi konsumen untuk membeli atau kembali membeli produk ini karena nilai dan citra merek yang baik, bisa dipercaya dan terbangun kokoh.

\subsubsection{Pemasaran yang Menginte-} grasikan Kesempurnaan dalam Mutu Produk, Pelayanan Purna Jual dan Ekuitas Merek Akan Menyebabkan Produk Smartphone Android Samsung Memiliki Citra Merek yang Dipandang Sukses di Pasar

Merek Samsung adalah fokus pada mutu produk baik detail produk maupun proses, pelayanan sempurna yang baik untuk purnajual serta pengenalan yang intensif ekuitas merek yang baik dan kuat sehingga citra merek produk ini akhirnya bisa terbentuk dalam potret yang baik dan kuat. Dan ketiga hal itu (mutu produk, pelayanan purna jual dan ekuitas merek) secara simultan ikut membangun citra merek produk ini di pasaran. Upaya-upaya mendasar dalam mencapai citra merek yang kuat setidaknya terlihat dari hal-hal seperti:

1.Fokus yang kuat pada pengelolaan yang serius mutu produk dan proses dari hulu ke 
hilir, dari praproduksi hingga pascaproduksi, dari perencanaan hingga pemasaran.

2.Peningkatan pelayanan purna jual dengan tetap mengawal mutu produk dan mengenalkan ekuitas merek untuk citra merek yang diharapkan bisa dikenal luas dan pantas.

3.Membangun reputasi merek itu sendiri.

4.Memperbarui daya tarik konsumen terhadap merek.

5.Penciptaan pelayanan berbasis mutu dan nilai merek untuk kesetiaan pelanggan terhadap merek sekaligus merepresentasikan citra merek yang hebat dan kuat. Integrasi hal-hal diatas akan senantiasa membentuk kuatnya citra merek produk khususnya di mata konsumen yang setia.

\section{KESIMPULAN}

Hasil penelitian ini mengungkapkan bahwa:

1.Terdapat Pengaruh positif antara mutu produk dengan citra merek.

2.Terdapat Pengaruh positif pelayanan purnajual dengan citra merek.

3. Terdapat Pengaruh positif antara ekuitas merek dengan citra merek. 


\section{DAFTAR PUSTAKA}

Anon. BRANDZ ${ }^{\mathrm{TM}}$ Top 100 Most Valueable Global Brands 2013, (www.millwardbrown.com/brandz/2013/Top100/Docs/ 2013_BrandZ_Top100_Chart.pdf).

Balaji N. Krishnan dan Michael D. Hartline.2001. "Brand Equity: Is It More Important in Services?”, Journal of Service Marketing, Vol.15, No.5, p.328.

Brandcareers-glossary, p.1, 2014 (http://www.brandchannel.com/education_glossary.asp).

Chevalier, Michael dan Gerald Mazzalovo. 2004. Brand As a Factor of Progress. Terjemahan Joe Lacour. New York: Palgrave McMillan.

Cohen, Heidi. 30 Branding Definition. 2011. (http://heidicohen.com/30-branding-definitions/).

Dahlgaard, Jens J., Kai Kristensen dan Gopal K. Kanji. 2007. Fundamentals of Total Quality Management. London and New York: Taylor and Francis.

Hermawan Kartajaya. 2005. Positioning Differentiation and Brand, Jakarta: PT Gramedia Pustaka Utama.

Hair, J.F. Jr., Anderson, R.E., Tatham, R.L. and Black, W.C. 1995. Multivariate Data Analysis, $3^{\text {rd }}$ edn. New York:Macmillan.

ISO, 2008. International Standard ISO 9001: Quality Management Systems-Requirements, Edisi ke-4, Switzerland: ISO Copryright Office.

Jay Schlickman, 2003. ISO 9001:2000 Quality Management System Design, Boston, London: Artech House.

Jean N. Kapferer, 2008. The New Strategic Brand Management: Creating and Sustaining Brand Equity Long Term, Edisi ke-4, London: Kogan Page.

John S. Oakland, 2003. Total Quality Management: Text with Cases, Edisi ke-3, Great Britain: ButterworthHeinemann.

Jonas Hansson dan Bengt Klefsjö, 2003. “A Core Value Model for Implementing Total Quality Management in Small Organisations", The TQM Magazine, Vol.15, Nr.2.

Kevin L. Keller, 1993. How to Manage Brand Equity, Jakarta: Gramedia Pustaka.

Krishnan, Balaji N. dan Michael D. Hartline, 2001. "Brand Equity: Is It More Important in Services?”, Journal of Service Marketing. Vol. 15. No. 5. p.328.

Lomas, N. (2014, January 29). Android Took 79\% Global Share of Smartphones in 2013 - But Grew at Its Lowest Rate Yet, Say Analyst. (https://techcrunch.com/2014/01/29/android-79-ios-16-wp-4/)

M. G. Parameswaran, 2006. Building Brand Value: Five Step to Build Powerful Brands, New Delhi: Tata McGraw-Hill.

Philip Kotler dan Gary Armstrong, 2012. Principle of Marketing, Upper Saddle, N.J.: Pearson Prentice Hall.

Philip Kotler, 2002. Manajemen Pemasaran: Jilid ke-2, Edisi Milenium, Terjemahan: Benjamin Molan, Jakarta: Pearson Education Asia Pte. Ltd. dan PT Prenhallindo.

Tjiptono, F. 2005. Brand Management and Strategy. Yogyakarta: Penerbit Andi.

Yoo, B. dan N. Donthu, Developing and Validating a Multidimensional Consumer-based Brand Equity Scale, Journal of Business Research, 52(1) 